\title{
STUDENTS' COMPETENCE IN INTERPRETING DEIXIS IN DESCRIPTIVE TEXT ON PRAGMATICS COURSE OF ENGLISH LETTERS DEPARTMENT OF UNIVERSITAS AHMAD DAHLAN
}

\author{
Garda Arif Wicaksono
}

\author{
Magister Pendidikan Bahasa Inggris \\ Universitas Ahmad Dahlan, Yogyakarta \\ Jalan Pramuka No. 42, Umbulharjo, Yogyakarta \\ Email: garda_arifw@yahoo.co.id
}

Submitted: 2018-10-21

Accepted: 2019-01-20

Published: 2019-02-01

\begin{tabular}{ll}
\hline Keywords: & Abstract \\
\hline pragmatics & The purpose of this research was to: 1) investigate the students' \\
deixis & competences in interpreting deixis in descriptive texts, 2) to find out \\
descriptive text & the students' difficulties in interpreting the types of deixis. In this \\
& research the researcher used quantitative approach. The research \\
& uesd twenty students of English Letters at pragmatics course as \\
& research subjects. The data were collected through test.The result of \\
& this research showed that their competence in interprating person \\
deixis was good (50\%), time deixis was excellent (55\%), discourse & deixis was excellent (45\%), social deixis was excellent (55\%), and \\
place deixis was good (55\%). It could be concluded that the & students' had good competence in interpreting deixis. However, \\
& most of them were mistaken in interpreting discourse deixis. This \\
& was because they had limited vocabularies, less understanding on \\
the context of descriptive text, and had difficulty to comprehend the \\
situational information in the descriptive text.
\end{tabular}

\section{INTRODUCTION}

This research focuses on determining the students' competence in interpreting deixis which is used in a descriptive text. This research was conducted in English Letters Department. Since pragmatics is one of the compulsory subjects in English Letters Department, English Letters Department student as participants of this reserach.Understanding deixis is very important in language learning. It is one of the aspects of linguistics which helps the students to understand the messages or information from the utterances. By understanding it, the readers as well as the students will broaden their knowledge, especially knowledge about cultures. Deixis is interpreted relatively based on the relation to a specific speaker, addressee, time, and place of utterance. In brief, it can be said that the interpretation of deixis will be different for every people depending on do the context and relation of the speaker and the addressee in a speech event. 
Deixis actually can be found in daily life communication in spoken or written form, in formal or informal situation, without realizing we use it for example when the readers get a new text, they need to get information about who are the speaker and the hearer, where, and when the events take place. The information can be accessed the understanding the written text. Based on those problems, the researcher conducted this study in English Letters Department in Universitas Ahmad Dahlan. The researcher gave a task to the students to measure their competence in deixis through descriptive text.

In fact, deixis is used in daily life by the society. They may happen either at home, school, office or campus in formal or informal situations, whether in the form of oral or written. The students often find deixis while reading a storybook, short story, novel or watching but most of them are still confused on how on interpret the deixis. Undergraduate students in English Letters Department of UniversitasAhmad Dahlan have taken pragmatics course.They also learn from the field study and get knowledge from their lecturers' explanation. The learning strategies in doing the discussion in the class usually assign a which given by the lecturers and read some texts from many resources. Based on the above statement, it is interesting to analyze deixis because students have studied deixis in the pragmatics subject. To investigate the students' competence in interpreting deixis in descriptive texts and to find out of the students' difficulties in interpreting the types of deixis.

There have been some previous studies related to deixis. One relevant study is the study which is done by Maspufah (2015: 1). The title is 'Students' Competence in Interpreting Deixis in the Narrative text at Grade XI IPA 1 Students of SMA Dharma Loka Pekanbaru'. In this study, a deixis is a tool for understanding speech in speech acts or written text. This study aims to determine students' competence in interpreting deixis in narrative texts. The type of the research is descriptive. The subject of this research is the students of class XI IPA 1 in SMA Dharma Loka Pekanbaru. The results of this study indicate that the students' competence in interpreting (1) the deixis persona in the narrative text is categorized as good, the students have difficulty in interpreting the deixis persona which refers to the sentence and the implicit references (2) the place deixis in the narrative text is categorized as good, (3) the deixis of time in the narrative of the text is categorized as good, the students are having difficulty in determining the time of the utterance and the use of time, (4) textual deixis on narrative text is categorized good, the students are difficult to understand the context, the situation, and the vocabulary used, (5) social deixis on narrative texts are well categorized.

The content of the journal written by Maspufah (2015) is very good on grammar, she write it systematically. After reading the journal the researcher finds some mistakes. In Maspufah's (2015) research uses mixed method (qualitative and quantitative). On finding and discussion, she writes the result of the test but she does not write the result of the interview. She writes the findings without discussion them on her discussion and also she still uses old references. Thus, by these conditions, the researcher assumes that it needs to be researched.

Based on the above phenomena faced by the students at Universitas Ahmad Dahlan especially English Letters Department, this research tries to solve the problem. The title of this research is " Students' Competence in Interpreting Deixis in Descriptive text on 
Pragmatics Course of English Letters Department of Universitas Ahmad Dahlan in 2017/2018".

Deixis is a reference of an expression which is relative to the (usually) extralinguistic context of the utterance such as who is speaking, the time or place of speaking, the gesture of the speaker, the current location (Levinson, 1995: 75). Yule (2005:9) states that deixis is a technical term for one of the most basicthings which are done in the utterances. Hurford, Heasley,\& Smith (2007:66) say that deixis word is one which takes some elements of its meaning from the context of the situation. Types or the categories of deixis are person deixis, place deixis, time deixis, discourse deixis and social deixis.

Maximilian (2013: 13) says that person deixis is some deictic expressions which are used to replace the name of persons. Most of the person deixis is a pronoun or calling name. Person deixis usually localizes a referent in relation to the position of the speaker or the hearer. A pronoun for the first person (I), second person (you) and third person ( he, she or it) and pronoun like this person, this man, the car, these houses, etc are also deictic because they require situational information for the listener to make out the referents or the meanings.

According to Huang (2007:149-150). Spatial deixis is indicated by location in the speech event. It usually uses the orientational terms such as up,down,front/back and left/right, frame in place of topological terms such as in, on or above/below/over/under. Maximilian(2013:16) states that place deixis is a deictic expression which is used to indicate a location of a participant in the speech event, typically the speaker.

Temporal or time deixis concerns with the encoding of temporal points and spans relative to the time when an utterance is spoken. Temporal deixis is commonly grammaticalized in deictic adverbs of time (like in English,the words 'now' and 'then' or 'yesterday' and 'this year' ) but they are all in tenses. Yule(1996: 15) mentions that English has two basic forms of tenses there is presentand past tense.

Levinson (1995: 76-77) states that discourse deixis should be distinguished from a related notion of anaphora. Discourse deixis shares with anaphora and cataphora of the capacity which has functioned as a text cohesion device. Fromkin, Rodman, \& Hyams (2007: 202-203). It contains the demonstrative article. Demonstrative articles are divided into four types there are this, that, these and those.

Maximilian (2013:20) states that social deixis concerns the social information which is encoded within various expressions, such as relative social status and familiarity. Social deixis is a reference to the social characteristic or distinctions between the participants or referents in a speech event. It is also stated that some deictic expressions are used to replace the honorifics, the higher the status of a person. The example of social deixis is a prince, teacher, sheriff, captain, professor, etc. Its purpose is to describe and reveal a particular person, place or thing. The objectives of this study are 1) to investigate the students' competences in interpreting deixis in descriptive texts on pragmatics course. 2) to find out the students' difficulties in interpreting the types of deixis.

\section{METHOD}

This reserach is conducted at of undergraduate students in English Letters Department of Universitas Ahmad Dahlan which taken of pragmatics course which compulsory at English Letter Department.

This research was descriptive quantitative as the research design. Descriptive is quantitative is used in this research because to explain the results of the data in the 
descriptive form. Quantitative research is research method dealing with numbers and anything which is measurable in a systematic way of investigation of the phenomena and their relationship (Leedy, 1993:87-88). In addition, quantitative research is a research that provides more detail description of a symptom-based on existing data, presenting data, analyzing and interpreting. The purpose of using quantitative research is to know the value of an independent variable, either one variable or more without making comparisons, or connecting with other variables (Sugiyono, 2012: 13). Quantitative research is used to examine the population or specific samples. The data are collected by using a research instrument. Then, data are analyzed quantitatively using Sugiyono's framework (2013).

\section{RESULTS AND DISCUSSION}

Table 1. Students' Competence in Interpreting Deixis in Descriptive texts

\begin{tabular}{cccc}
\hline Score & $\begin{array}{c}\text { Number of } \\
\text { Students }\end{array}$ & Percentage & Category \\
\hline $90-100$ & 8 & $40 \%$ & Excellent \\
$80-89$ & 9 & $45 \%$ & Good \\
$70-79$ & 2 & $10 \%$ & Fair \\
$60-69$ & 1 & $5 \%$ & Poor \\
$0-59$ & 0 & $0 \%$ & Very Poor \\
\hline
\end{tabular}

It can be concluded that the students' competence in interpreting deixis is good. Their average score is 85.8. In the presented table, it shows that the most students are competence in good category score between 80-89 or nine students are in good category $(45 \%)$. Then, eight students are in excellent category score between 90-100. Two students are fair category score $70-79(10 \%)$ and only one student is in poor category score 60-69 $(5 \%)$.

Table 2. Students' Competence in Interpreting in the Types of Deixis

\begin{tabular}{cccc}
\hline Types of Deixis & $\begin{array}{c}\text { Number of } \\
\text { Students }\end{array}$ & Percentage & Category \\
\hline Person Deixis & 10 & $50 \%$ & Good \\
Place Deixis & 11 & $55 \%$ & Good \\
Time Deixis & 11 & $55 \%$ & Excellent \\
Social Deixis & 11 & $55 \%$ & Excellent \\
Discourse & 9 & $45 \%$ & Excellent \\
Deixis & & &
\end{tabular}

In general, table 2 describes the results which are obtained by the students in interpreting types of deixis. Table 9 is obtained from tables 3-7. The total population and sample in this research are 20 students and the students are prepared the determine the students' competence in interpreting each type of deixis.

Based on the table above, the number of percentage of students' ability in interprating the person deixis is 50\%. The students who are competent in interpreting the deixis can be described as; (1) about 10 students from 20 students are good at interpreting person deixis. (2) about 11students from 20 students are good in interpreting the place deixis, or it is about 55\%; (3) the students who get excellent category in time deixis are about 11 
Garda Arif Wicaksono, Students' Competence In Interpreting Deixis... .

students from 20 students or it is about $55 \%$; (4) the students who get excellent category in interpreting the social deixis are about 11 students from 20 students or it is about 55\%; and (5) about 9 students from 20 students are excellent categorized in interpreting discourse deixis $(45 \%)$.

Table 3. Students' Competence in Interpreting Person Deixis

\begin{tabular}{cccc}
\hline Score & $\begin{array}{c}\text { Number of } \\
\text { Students }\end{array}$ & Percentage & Category \\
\hline $90-100$ & 8 & $40 \%$ & Excellent \\
$80-89$ & 10 & $50 \%$ & Good \\
$70-79$ & 0 & $0 \%$ & Fair \\
$60-69$ & 2 & $10 \%$ & Poor \\
$0-59$ & 0 & $0 \%$ & Very Poor \\
\hline \multicolumn{4}{c}{} \\
\hline
\end{tabular}

Some of the students still make mistake in interpreting the person deixis in descriptive text. Based on the table above, we know that about $10 \%$ are poor in interpreting the deixis, $50 \%$ have good competence in interpreting deixis, and $40 \%$ of the students get excellent in interpreting person deixis. Person deixis is a multiple-choice form which is on question numbers $1,5,8,15$ and 21 . In this case, the researcher should provide more various questions to the students. In pragmatics course, some students make mistakes on numbers:

One of my favorite places for vacation in Mexico. I really the weather because it never gets cold there. The people are very nice, too. They laugh at my bad Spanish and the food is wonderful. Mexico is very interesting to visit. It has some great museums and lots of fascinating old buildings and the hotels are not too expensive. But you can stay in other places in Mexico. For example, you should go to one of the beach resorts like Acapulco and you shouldn't miss the Mayan temples near Merida.

1. The word "I" in the second line refers to

$\begin{array}{ll}\text { a. } & \text { The Writer } \\ \text { b. } & \text { John } \\ \text { c. } & \text { James } \\ \text { d. } & \text { Celia }\end{array}$

Paris is the capital of the European nation, France. It is also one of the most beautiful and most famous cities in the world.

Paris is called the City of Light. It is also an international fashion center. What stylish women are wearing in Paris will be worn by women all over the world. Paris is also famous for its world center of education. For instance, it is the headquarters of UNESCO, the United Nations Educational, Scientific and Cultural Organization.

The Seine River divides the city into two parts. Thirty-two bridges cross this scenic river. The oldest andperhaps the most well-known is Pont Neuf, which was built in the sixteenth century. Sorbonne, a famous university, is located on the left bank (south side) of the river. The beautiful white church Sacre Coeur lies on the top of a hill called Montmartre on the right bank (north side) of the SeineThere are many other famous places in Paris, such as the famous museum the Louvre as well the cathedral of Notre 
Dame. However, the most famous landmark in this city must be the Eiffel Tower.

Paris is named after a group of people called the Parisii. They built a small village on an island in the middle of the Seine River about two thousand years ago. This island is called Ile de la Cite. It is where Notre Dame located. Today around eight million people live in the Paris area.

5. The word "They" refers to

a. People

b. Parisii

c. Million people

d. Scientist

There is the analysis of students competence on question number 1,5,8,15, and 21 . Many students choose the correct answer in those five numbers. In the question number 1 , about 19 students have the correct answers, about 17 students answer in question number 5, 17 students in the question number 8,17 students in question number 15 and about 16 students in the question number 21 .

Table 4. Students' Competence in Interpreting Place Deixis

\begin{tabular}{cccc}
\hline Score & $\begin{array}{c}\text { Number of } \\
\text { Students }\end{array}$ & Percentage & Category \\
\hline $90-100$ & 6 & $30 \%$ & Excellent \\
$80-89$ & 11 & $55 \%$ & Good \\
$70-79$ & 0 & $0 \%$ & Fair \\
$60-69$ & 2 & $10 \%$ & Poor \\
$0-59$ & 1 & $5 \%$ & Very Poor \\
\hline
\end{tabular}

Some of the students still make mistake in interpreting place deixis in descriptive text. Based on the table above, we can know that $10 \%$ of the students are poor in interpreting place deixis, $0 \%$ of students is fair, 55\% of students are good competence, and $30 \%$ the students got excellent in interpreting place deixis. Place deixis can be found on question numbers $4,2,12,14$, and 17 . In this case, the researcher should provide a more various question to the student. In Pragmatics Course. Some students make mistakes on numbers:

The Seine River divides the city into two parts. Thirty-two bridges cross this scenic river. The oldest andperhaps the most well-known is Pont Neuf, which was built in the sixteenth century. Sorbonne, a famous university, is located on the left bank (south side) of the river. The beautiful white church Sacre Coeur lies on the top of a hill called Montmartre on the right bank (north side) of the SeineThere are many other famous places in Paris, such as the famous museum the Louvre as well the cathedral of Notre Dame. However, the most famous landmark in this city must be the Eiffel Tower.

4. The word "this" refers to
a. $\quad$ Cathedral of Notre Dame
b. Museum the Louvre
c. Paris
d. Eiffel Tower 
The palace court with its grand and elegant Javanese architecture lies in the center of the city. Prince Mangkubumi founded the palace in 1755. The Prince then was called Sri Sultan Hamengkubuwono I and he chose the right location of the compound between Winongo River and Code River. The palace stretches out from north to south. The front yard is called Alun-Alun Utara (the North Square), and the backyard is called Alun-Alun Selatan (the South Square).

17. What does the sentence "The palace stretch out from north to south" in line refers to?
a. Backyard
b. $\quad$ The buildings
c. The north square and the south square
d. Winongo river and code river

In the analysis of the students' competence on question number $2,4,12,14$, and 17 , they show that there are 19 students. Choose the correct answer in the question number 2 , 15 students in the question number 4, 17 students in the question number 12, 16 students in the question number 14, and 15 students in the question number 17.

Based on the analysis above, some of the students get a problem in interpreting place deixis especially for question number 4,14 , and 17 . Students have difficulty to identify the location of the participant in the speech event. They also have limited vocabulary, so this condition made them difficult in interpreting the object, location or positions in the speech event.

Table 5. Students' Competence in Interpreting Time Deixis

\begin{tabular}{cccc}
\hline Score & $\begin{array}{c}\text { Number of } \\
\text { Students }\end{array}$ & Percentage & Category \\
\hline $90-100$ & 11 & $55 \%$ & Excellent \\
$80-89$ & 7 & $35 \%$ & Good \\
$70-79$ & 0 & $0 \%$ & Fair \\
$60-69$ & 1 & $5 \%$ & Poor \\
$0-59$ & 1 & $5 \%$ & Very Poor \\
\hline
\end{tabular}

Some of the students still make mistake in interpreting time deixis in descriptive text. Based on the table above, we can know that $5 \%$ of the students are poor in interpreting time deixis, $0 \%$ of students are fair, 35\% of students have good competence in interpreting deixis and 55\% of the students get excellent in interpreting place deixis. Time deixis can be seen on question numbers $6,7,9,19$, and 23. In this case, the researcher should provide more various questions to the students. In pragmatics course, some students make mistakes on numbers:

In winter, we can find snow everywhere. It is always very cool. The temperature can be lower than $0^{\circ} \mathrm{C}$. you should wear a jacket if you want to go out. We usually have winter from December to February. After winter, we have sprung from March to May. The snow melts down. It is the time when trees and plants start to grow their leaves. The temperature is warmer than before, we also have a lot of rain.

Then, it is summer! We have the summer from June to August. The sunshine very brightly and it is a holiday time. We finish out school and we can play all day or travel to 
another place. We usually visit our relatives in the different city. It is sometimes very hot and people go to the beach or swimming pool.

6. What seasons are indicated by the phrase

"Then" in the last paragraph
a. Winter
b. Autumn
c. Spring
d. Summer

Two years after obtaining the degree of Doctor Honoris Causa, he died on April 28, 1959, in Yogyakarta and is buried there.

Day of birth celebrated as National Education Day.

Famous teachings are

" tut wuri handayani " (behind giving encouragement),

" ing middle Mangun intention " (in the middle of

creating opportunities for initiative),

" ing ngarsa sungtulada"

23. What year is indicated by "two years after"?

a. $\quad 1957$

b. 1958

c. 1959

d. 1960

In the analysis of students competence on question number $6,7,9,19$, and 23 , it can be described;(1) 16 students choose correct answer in the question number 6; (2) 18 students choose correct answer in question number 7; (3) 18 students choose correct answer in the question number 9; (4) 20 students choose correct answer in the question number 19 and (5) 16 students choose correct answer in the question number 23.

Based on the analysis above, some students get the problem in interpreting time deixis especially for question number 6 and 23 . The students are difficult to identify the specific time becausethe students have less competence in grammar related to the change form of the verb in every tenses and adverb of time.

Table 6. Students' Competence in Interpreting Discourse Deixis

\begin{tabular}{cccc}
\hline Score & $\begin{array}{c}\text { Number of } \\
\text { Students }\end{array}$ & Percentage & Category \\
\hline $90-100$ & 9 & $45 \%$ & Excellent \\
$80-89$ & 7 & $35 \%$ & Good \\
$70-79$ & 0 & 0 & Fair \\
$60-69$ & 3 & $15 \%$ & Poor \\
$0-59$ & 1 & $5 \%$ & Very Poor \\
\hline
\end{tabular}

Some of the students still make mistake in interpreting discourse deixis in descriptive text. Based on the table above, we can know that $15 \%$ of the student is poor in interpreting discourse deixis, $0 \%$ of students isfair, $35 \%$ of students has good competence in interpreting discourse deixis, and $45 \%$ the students get excellent in interpreting place deixis. Discourse deixis can be seen on question numbers 3,11, 13, 18, and 24. In this 
Garda Arif Wicaksono, Students' Competence In Interpreting Deixis... .

case, the researcher should provide the more various questions to the students in pragmatics course. Some students make mistakes on numbers:

Raja Ampat or The Four Kings is a famous island located off the northwest tip of Bird's Head Peninsula on the island of New Guinea, in Indonesia's West Papua Province. It's well known as a diving heaven for people around the world.

Raja Ampat covers 9.8 million acres of land and sea, home to 540 types of corals, 1,000 types of coral fish and 700 types of mollusks. it makes Raja Ampat as the most diverse living library for world's coral reef and underwater biota. Besides that, Raja Ampat has a beautiful scenery, especially from its underwater corals and its beach.

13. What does the word "that" in line 15 refers to?

a. Raja Ampat is a famous island.

b. Raja Ampat as the most diverse living library for world's coral reef.

c. Raja Ampat as the most diverse living library for world's coral reef and underwater biota.

d. Raja Ampat has beautiful scenery

Obama was born on 4 August 1961, Honolulu, Hawaii, USA. His complete birth name is Barrack Hussein Obama Jr but he is popular called Barrack Obama instead of his four nicknames: Barry, Bama, Rock, and The One. His mother is Ann Dunham, a white American. And his father is Barrack Obama Sr, a black Kenyan. After his parents divorced, Obama experienced living in Indonesia when he was six as his mother married an Indonesian Oil manager Lolo Sutoro.

He lived in Indonesia for not morethan two years than returned to the US to grow up and study. That became sufficient reason why he was so popular in Indonesia. Obama began his career in 2004 when he was elected to the U.S. Senate as a Democrat, representing Illinois, and gained national Convention in Boston. In 2008 he ran for president as a Democrat and won.

24. What does the word "that" in the second paragraph refers to?

a. Obama began his career in 2004

b. In 2008 he ran for president as a Democrat and won.

c. He successfully won the vote for 44th president for the US after defeated John M'chain

d. He lived in Indonesia for not more than two years than returned to the US to grow up and study

In the analysis of students competence on question number $3,11,13,18$, and 24 , it can be described; (1) 18 students answers true choose correct answer in the question number 3 ; (2) 18 students choose correct answer in the question number 11; (3) 13 students choose correct answer in the question number 13; (4) 18 students choose correct answer in the question number 18 and (5) 17 students choose correct answer in the question number 24 .

Based on the analysis above, some of the students get the problem in interpreting discourse deixis especially for question number 13 and 24. Some of the students have difficulties to see the context in understanding the story. They are not able to make the connection and comprehend the situational information in a descriptive text. 
Table 7. Students' Competence in Interpreting Social Deixis

\begin{tabular}{cccc}
\hline Score & $\begin{array}{c}\text { Number of } \\
\text { Students }\end{array}$ & Percentage & Category \\
\hline $90-100$ & 11 & $55 \%$ & Excellent \\
$80-89$ & 7 & $35 \%$ & Good \\
$70-79$ & 2 & $10 \%$ & Fair \\
$60-69$ & 0 & $0 \%$ & Poor \\
$0-59$ & 0 & $0 \%$ & Very Poor \\
\hline
\end{tabular}

Some of the students still make mistake in interpreting social deixis in descriptive text. Based on the table above, we can know that $10 \%$ of the student is fair to in interpreting social deixis, $35 \%$ of students are good, $55 \%$ of students have the excellent competence in interpreting social deixis. Social deixis can be seen on question numbers 10, 16, 20, 22 and 25. In this case, the researcher should provide more various questions to the students. In pragmatics course, some students make mistakes on numbers:

He was previously the mayor of Surakarta(often also known as Solo in Indonesia). He was nominated by his party, the Indonesian Democratic Party-Struggle, to run in the 2012 Jakarta gubernatorial election.Jokowi's national popularity has risen sharply since his election to the high-profile position of governor of Jakarta. He is now seen as a strong potential candidate for the Indonesian presidential election in 2014.

10. What does the phrase "high profile" refers to?
a. Governor
b. Joko Widodo
c. President
d. Politicians

The palace court with its grand and elegant Javanese architecture lies in the center of the city. Prince Mangkubumi founded the palace in 1755. The Prince then was called Sri Sultan Hamengkubuwono I and he chose the right location of the compound between Winongo River and Code River. The palace stretches out from north to south. The front yard is called Alun-Alun Utara (the North Square), and the backyard is called Alun-Alun Selatan (the South Square). The layout of the buildings shows that the Palace, the commemorative column, and Mount Merapi lie in one line. The palace meeting hall is called Pagelaran, where formal meetings of palace officials are held, while the "Manguntur Tingkil" hall is the place where the Sultan is seated.

16. What does the word "Prince"refers to?

a. Sri Sultan Hamengkubowono I

b. Gusti Raden Mas Dorodjatun

c. Sri Sultan Hamengkubuwono $X$

d. Visitor 
In the analysis of students competence on question number 10, 16, 20, 22 and 25, it can be described; (1) 14 students choose correct answer in the question number 10; (2) 17 students choose correct answer in the question number 16; (3) 20 students choose correct answer in the question number 20; (4) 20 students choose correct answer in the question number 22; and (5) 18 students choose correct answer in the question number 25.

Based on the analysis above, some of the students get the problem in interpreting social deixis especially for question number 13 and 24. Some of the students are difficult to see the context and understand the story. Theycannot make the connection and comprehend the situational information in a descriptive text.

\section{Students' Competence in Interpreting Deixis in Descriptive Text}

Uzer (2006) states that competence is the ability or skill. Uzer (2006) also says that competence is a rational behavior to achieve the required goals as expected. Competence of a student can be hard skills and soft skills, hard skills are easily observed technical tasks, reviewed, and measured while soft skills are non-academic skills (personal, interpersonal and problem-solving skills) (Agustin, 2012: 3).

Based on the table eight page 48. The average score is 85.8 . It is because most of the students are competing in interpreting deixis. It is between 80-100 or about seventeen students are on good to excellent categorized (85\%). It is because the students of English Letters at Universitas Ahmad Dahan often use deixis in everyday life both in oral and written form.In daily life, the students often use four types of deixis are person, place, time deixis and social.For example, when they read articles on the internet or conversations with friends of this four deixis is often used, so that the four types of deixis is considered easier by students of English Letters Department at the Universitas Ahmad Dahlan.

\section{The Students' Difficulties in Interpreting Types of Deixis}

The student difficulties are a heterogeneous condition which has fundamental psychological functions (Jamaris, 2014: 50-51). In addition, student difficulties are influenced by two factors; internal (self) and external factors (student environment).

Based on table 3-7, it shows that about $90 \%$ of students' competence in interpreting person deixis, $85 \%$ of students' competence in interpreting place deixis, $90 \%$ of students' competence in interpreting time deixis, $90 \%$ of students' competence in interpreting social deixis, and $80 \%$ of students' competence in interpreting discourse deixis.

The results show that person deixis, place deixis, time deixis and social deixis are easiest for students because students are often used them when communicates within the society or campus both oral and written form. Discourse deixis is still problematic for the students, especially in the form of writing because discourse itself is only learned by students in pragmatics course. Moreover; (1) the students have less understanding the context of the story; (2) the student is not able to make the connection and; (3) the students have difficulty to comprehend the situational information in a descriptive text.

\section{CONCLUSION}

\section{Students' Competence in Interpreting Deixis in Descriptive Text}

The findings indicate that the students' competence in interpreting deixis in the descriptive text is good to excellent because the students of English Letters Department at Universitas Ahmad Dahlan are often used deixis in their daily life both in oral and written form. They use four types of deixis. They are person, place, time dan social deixis, for example, when they are read articles on the internet or make conversation with their 
friends, four deixis are often used. Therefore, the four types of deixis are considered easier by the students of English Letters Department at the Universitas Ahmad Dahlan.

\section{The Students' Difficulties in Interpreting Types of Deixis}

The results show that deixis, place deixis, time deixis and social deixis are easy for the students to interprate because they often use them when having communication within the society or campus both oral and written. Discourse deixis is difficult for the students to understand especially in the form of writting because it is learned merely in the pragmatics course. Moreover, the students do not understand the context the story, are not able to make the connection, and have difficulty to comprehend the situational information in a descriptive text.

\section{REFERENCE}

Huang, Y. (2007). Pragmatics. New York: Oxford University Press.

Hurford, J., Brendon, H., \& Michael, B.S. (2007). Semantics: A Coursebook. Cambridge: Cambridge University Press.

Leedy, P.D.(1993). Practical Research: Planning and Design. $5^{\text {th }}$ ed. New York: Mackmillan Publishing Company.

Levinson, S. C. (1995). Pragmatics. Cambridge: Cambridge University Press.

Maximilian,A. \& Ajeng, G.D. (2013). Pragmatics in Language Teaching. Yogyakarta: Deepublish.

Sugiyono, (2012). Memahami Penelitian Kualitatif. Bandung: ALFABETA. (2013). Metode Penelitian Pendidikan (Pendekatan Kuantitatif, Kualitatif dan $R \& D$, Bandung : Alfabeta.

Yule, G. (2005). Pragmatics. New York: Oxford University Press. (1996). Pragmatics. New York: Oxford University Press. 